\title{
"Put a meeting in my calendar!" The literacy practice of the digital calendar in workplaces
}

Tidsskriftet Sakprosa

Bind 11, Nummer 1

(C) 2019 


\section{Sammandrag}

I dagens arbetsliv används många digitala redskap av vilka den delade digitala kalendern knappast har uppmärksammats inom tillämpad språkvetenskap. Ramen för studien är medierad diskursanalys, som här används på etnografiska data från en arbetsplats och åtta kontextuella intervjuer från åtta andra arbetsplatser. Materialet analyseras med fokus på agentivitet 1) kvalitativt utifrån Wertschs (1998) begrepp kring agentivitet, 2) och kvantitativt genom en SFG (Systemisk-funktionell grammatik)-analys av intervjuerna. Den kvantitativa analysen visar en upplevd hög nivå av agentivitet. Den kvalitativa analysen spårar en ledarskapsdiskurs och diskurser förknippade med globalisering, demokratisering och "platta organisationer” från den digitala kalendern. Den kan också kopplas till andra textmedier som tidrapportsystem och whiteboardtavlor, där rutor med färg och skrift är en gemensam diskursiv utformning med den digitala kalendern. Möjligheten att söka och boka i andras kalendrar är en affordans som dock begränsas genom digital eller verbal access. På detta och andra sätt är individen starkt relaterad till det digitala redskapet. Gränsen mellan privat och offentligt har utmanats av digitala redskap. Sociala aktörer kan göra motstånd t.ex. genom att inte följa arbetsplatsens princip att använda delad kalender och på så sätt försöka öka sin agentivitet. Ett annat sätt är att kombinera flera olika medier och att utveckla egna praktiker som inte direkt erbjuds av verktygets design. Det digitala verktyget både ökar aktörers agentivitet, t.ex. genom möjligheten att hålla en mängd information samlad till ett möte, och begränsar den, eftersom de ibland upplever maktlöshet i vad de kan se i sin kalender. 


\begin{abstract}
Modern work life includes many digital tools, of which the shared digital calendar has attracted little attention in applied linguistics. The framework for this study is mediated discourse analysis applied to ethnographic data from one workplace and eight contextual interviews from eight other workplaces. The data were analyzed 1) qualitatively, using Wertsch's (1998) concepts for agency, and 2) quantitatively, through an SFG (Systemic Functional Grammar) analysis of the interviews. The quantitative analysis reveals a high degree of agency. The qualitative analysis shows that discourses of managerialism, globalization, democratization and "flat organizations" can be mapped to the digital calendar. The calendar is also related to other text media such as whiteboards and time report systems, where squares with colors and writing constitute the discursive shapes that are common to the digital calendar. The ability to search and book meetings in the calendars of others is an affordance, although regulated through digital or verbal access. In this and other ways, the individual is strongly connected to the digital tool. The boundary between private and public has been challenged by digital tools. Social actors can resist, e.g., by non-compliance in using the digital calendar, thus increasing their sense of agency. Additional features include the ability to combine different media and develop practices that are not directly offered by the design of the tool. The digital tool both widens the agency of the actors, e.g., in keeping a great deal of information connected to one meeting, and delimits it, e.g., in sometimes rendering individuals helpless to what they see in their own calendars.
\end{abstract}


Keywords: discourse analysis; digital media; writing practice; workplacecommunication; agency

About the authors:

Mona Blåsjö is Associate Professor of Scandinavian Languages at the Department of Swedish Language and Multilingualism, Stockholm University

Sofia Johansson is a master student and research assistant at the Department of Swedish Language and Multilingualism, Stockholm University

Carla Jonsson is Associate Professor of bilingualism at the Centre for Research on Bilingualism, Department of Swedish Language and Multilingualism, Stockholm University 


\section{"Put a meeting in my calendar!" The literacy practice of the digital calendar in workplaces}

\section{Introduction}

Modern text society is constantly developing (Berge 2007, Karlsson 2009, Kress 2009), and texts are, to an ever-increasing extent, being integrated with digital tools. Hence, the use of digital texts and tools has been studied within applied linguistics (Smart 2006, Darics 2017), but more often in educational settings than in work settings. The use of digital tools in work life is a frequent object of study within fields such as Human-Computer Interaction (e.g. Sharples 2012), but in applied linguistics is still under-researched. Studies such as Karlsson (2007) and Berge (2001) have problematized the concept of text and have covered texts such as Post-it-notes, thus addressing literacy practices and texts not attended to in earlier research. How discourses such as managerialism enter and influence public organizations through text has been examined by Tusting (2015) and Ledin and Machin (2015). In this article, we will study the use of digital calendars in modern workplaces, regarding it as a literacy practice involving several texts and text elements. The study forms a part of the research project 'Professional Communication and Digital Media. Complexity, Mobility and Multilingualism in the Global Workplace'.1

The focus on digital calendars was inspired by a pilot study in a bachelor thesis about a manager in a commercial company who experienced being governed by her digital calendar; without always knowing the purpose, she attended various meetings that other persons had put into her calendar, feeling like "a body just going in and out of rooms" (Gravett 2018, supervised

${ }^{1}$ Funded by the Marcus and Amalia Wallenberg Foundation, 2016-2019. 
by Jonsson). Although one can reject meeting invitations, the digital and shared mode of calendars such as Outlook has led to novel situations. This aroused an interest in investigating people's sense of agency in relation to shared digital calendars. Digital work tools are developed to enhance people's agency to accomplish things, but in which aspects can these tools also decrease sense of agency? Moreover, can users feel more or less as free agents in the practical use of the tools as such?

The general research interest behind the study, and what we wish to contribute, concerns how human actions are related to discursive artefacts including texts and digital tools. The more specific aim of the study is to generate knowledge and theoretical development on how individual and collective agency is related to discursive and digital artefacts by focusing on the literacy (or social) practice of communicating through shared digital calendars in the workplace. The research questions are:

1. How do people use shared digital calendars?

2. How do people speak about their calendars and related practices?

3. How can the literacy practice of using a shared digital calendar be related to issues of agency?

These research questions are used as headings for the empirical sections, following a research overview, theoretical background on the concept of agency, and a description of the method. 


\section{Previous research on digital calendars in the workplace}

There is a need for further study on the use of digital media in the workplace within applied linguistics. Fields such as Human-Computer Interaction and pedagogy have a longer tradition of studying the use of digital tools. Particularly interesting studies can be found in the interdisciplinary fields of Workplace Studies (e.g. Luff et al. 2000) and Computer Supported Cooperative Work (e.g. Schmidt \& Bannon 2013). These fields have taken an interest in the role of digital resources for so-called distributed cognition and work processes, i.e., how the work of the individual is related to collective knowledge in the workplace, and how this, in turn, is related to computer systems.

One such study, quite dated, but very relevant to this article, is Palen's (1999) investigation of the use of shared digital calendars in terms of social distinctions such as private and public. The participants in this particular study developed strategies to avoid being invited to meetings, such as entering fake appointments (Palen 1999:20). Most of the participants retained the default settings of their calendars, despite that changing them would have given them a higher degree of privacy and, perhaps, agency. Sharing one's calendar was not mandatory in the studied workplace, but through "subtle peer and institutional pressure” (Palen 1999:24) most employees still shared them, as "[r]estricted or closed calendars can challenge norms and expectations, and be perceived as unwillingness to reciprocate the trust others offer" (Palen 1999:21). The choice of employees to share their calendars was also related to the affordances of the calendar system: Temporal Orientation, Scheduling, Tracking, Reminding, Note recording/Archiving and Retrieval \& Recall (p. 19). Palen (1999) also revealed such actions as considering what was possible with respect to time, e.g., if a colleague needed travel time or if they had a deadline during a certain period. These different values for different 
time slots were often the basis for choices when inviting others (Palen 1999:21).

The value of time was also studied by Buzzo and Merendino (2015). They contend that the design of digital calendars do not show different values of time (such as work/free time and spatial aspects). Instead, the design solely "enforce[s] industrial and commercial assumptions on both the representations of time and our perception of time" (p. 490). Moreover, this design can be interpreted as Eurocentric, in its reading order from left to right (Buzzo \& Merendino 2015, cf. Hund et al. 2014). An event that is in the calendar is often prioritized over other events "even if it is actually less important, just because it is in the calendar" (Hassenzahl 2015:499), which may also be seen as an aspect of different values.

Several interesting studies were conducted by Geisler (2001, 2003, Golden \& Geisler 2006, 2007) on the use of "personal digital assistants", a precursor to the smart phone, on the issue of the role of texts and the boundary between work and private life. Golden and Geisler (2006) describe modern work life as a combination of a discourse of exploitation and a discourse of empowerment, where professionals are simultaneously expected to be available after work hours and are freer to influence their own planning through digital tools. Thus, the issue of agency is highly relevant for Geisler; one of her interviewees states that her digital device influences her sense of agency: "I don't really feel like I plan my week, I feel more like my week plans me” (Golden \& Geisler 2006:10). As a writing researcher, Geisler (2003) highlights the multitasking of modern work life, where writing only counts as one of several activities and modes, despite the crucial role played by texts. She also points to the technical affordances of a digital calendar compared to a paper calendar, such as the ability to write a recurring event only once to get it scheduled for several weeks (Geisler 2001:318). 
A struggle between discourses of agency versus surveillance, materialized in digital devices such as the calendar, can be found in previous research, where relationships between the collective and the individual, working hours and private life, and writing/text and other media/modalities are highlighted. These are all aspects of great relevance to applied linguistics that are examined in this study.

\section{The concept of agency}

Agency generally means "acting independently and making one's own choices" (Irwin 2011:100); in relation to literacy, Lillis (2013:81) provides the specification “individual control/action/opportunity”. In general scholarly discussions, the issue of whether agency or structure is responsible for governing human conditions has been fundamental. The answer to this has shifted, both between disciplines and fields, and from time to time: either general societal structures have been regarded as having the power over people, and thus of scholarly interest, or the individual has been the focus for studying choices of actions, seemingly independent of contextual conditions (on this dichotomy in sociolinguistics, see, e.g., Irwin 2011, Bell 2016). Among strands attempting to overcome such a dichotomic conceptualization, theories emanating from the Russian scholars Bakhtin (1986) and Vygotsky (1978) have been applied frequently in sociolinguistics. These theories build on the idea that people act out from what is given, thereby creating something partly new to be taken over by other actors (cf. Giddens 1984, Deumert 2014). That is, people cannot act completely separate from the given structures, but they can and do challenge and change the structures. In Vygotsky's works, however, what is given from the past is not conceptualized as structures, but as cultural tools or mediational means.

Although not emphasized by Bakhtin and Vygotsky themselves, the issue of agency from their tradition has been further theorized by Wertsch (1998), who 
contributes the distinction constraints and affordances (Wertsch 1998:3842). ${ }^{2}$ A cultural tool can either constrain the actor's agency or empower it offering affordances - or both. Wertsch gives the example of specific terms of language as offering opportunities to see and speak about something, and simultaneously constraining what we see and speak about. He also develops concepts for the actor's attitude fundamentally integrated with their agency: 1) resistance (an attitude of rejection, cf. Scollon 2001:106), 2) mastery (using it more or less correctly), or 3) appropriation (as an integrated part of their identity) with respect to a certain tool.

\section{Agency and other concepts of mediated discourse analysis}

Bakhtin, Vygotsky and Wertsch constitute a great deal of the basis of mediated discourse analysis (MDA, also called nexus analysis; Scollon \& Scollon 2004, Norris \& Jones 2005). The key issues of interest for MDA is how people (i.e. social actors) use tools and other discursive means (i.e. discourses) in concrete social actions and which role these discursive means have. The relationship between social actors and discourse 3 is conceptualized within the terms historical body and discourses in place. The historical body (Scollon \& Scollon 2004:160-161, Jones 2008:245) is the collected experiences and basis for the actions of a person, including the discursive aspects the person has in-

\footnotetext{
${ }^{2}$ Wertsch (1998) refers to Gibson's original concept of affordance, but applies it in a more general sense of 'advantage, positive effect'.
}

3 The Scollons use the concept discourse both for countable big Discourses (ways of interaction and thinking, e.g., management discourse, cf. Gee 1999) and for language in use, but, primarily, the latter (Scollon \& Scollon 2004:3-5, Scollon, Scollon \& Jones 2012:110113). 
corporated, such as written instructions and ways of speaking. According to MDA, social actors carry discourses within them, acting them out in relevant ways in different situations. The discourses made relevant and used in these situations are termed discourses in place (Scollon \& Scollon 2003, 2004:161165, Scollon 2008:21-22), as they are made present in these situations, while not in others. The third aspect present in these action situations is interaction order (Scollon \& Scollon 2004:13, Scollon \& Scollon 2003:212, from Goffman 1983), i.e., the social aspect of roles, division of labor, etc. For instance, the interaction order in a group can be changed when using a digital tool (Scollon \& Scollon 2004:50-55). The three aspects - historical body, discourses in place and interaction order - are relevant in all social actions and, accordingly, are key analytical concepts when studying human activity and use of tools.

In their conceptualization of agency, MDA researchers often emphasize intentions (e.g., S. Scollon 2005, Jones \& Norris 2005) and use the phrase “agency and free will” (e.g., Norris 2005:195). Discourses and literacy practices available for social actors influence their agency (Jones \& Norris 2005). MDA rejects the idea that individual actions can be studied regardless of context, as agency is "distributed among participants, mediational means and discourses" (Jones \& Norris 2005:171). For instance, agency to search information on Internet is intertwined with the means of Google, with Internet users providing information, and the modalities of that information. Moreover, Norris (2005:195) points out that "agency, although practiced in the immediate does not necessarily coincide with agency in higher levels of discourse", giving the example of a housewife in her study who in immediate interaction can claim that she does not wish to be dependent, although on a more general level, she has been so for quite some time. 


\section{Data and analytical approach}

When studying agency, we regard agency in terms of three levels:

- Within the actual digital tool - which are the competencies/digital literacies of the participants to use certain sub tools/functions within the tool?

- Immediate context - which affordances does the digital calendar offer participants; which work life activities are possible/easier to perform with the tool than without it (cf. Palen 1999, Lillis 2013)?

- Wider context - which aspects of 'big discourses' and interaction order are relevant in setting boundaries for the agency of participants in relation to the digital calendar?

This complex situation is in line with the MDA approach to agency as “distributed among participants, mediational means and discourses" (Jones \& Norris 2005:171).

\subsection{Data}

A set of ethnographic data was constructed during a year at a company that works with technological development (called case organization below). The organization is based in Sweden but has many international contacts. The key participant is Per, a male head of a unit, aged approximately 50, with a PhD. This data (called vertical data below, as it is quite in-depth, cf. Fig. 1) comprises five interviews with Per, four hours of observing Per's work at his computer, and observations of twelve meetings (2 video-recorded, 7 audiorecorded and 3 documented via field notes). All the authors were involved in 
this data construction, which was part of the general data construction for the bigger research project (see above).

To form a more heterogeneous image, we interviewed persons working in different sectors. The eight participants in this "horizontal data" (more shallow, used to get a broader picture; see Figure 1) were women aged 40-60. They volunteered as a response to invitations posted in social media, or were found in our professional and social networks. These participants worked in four different Swedish cities.

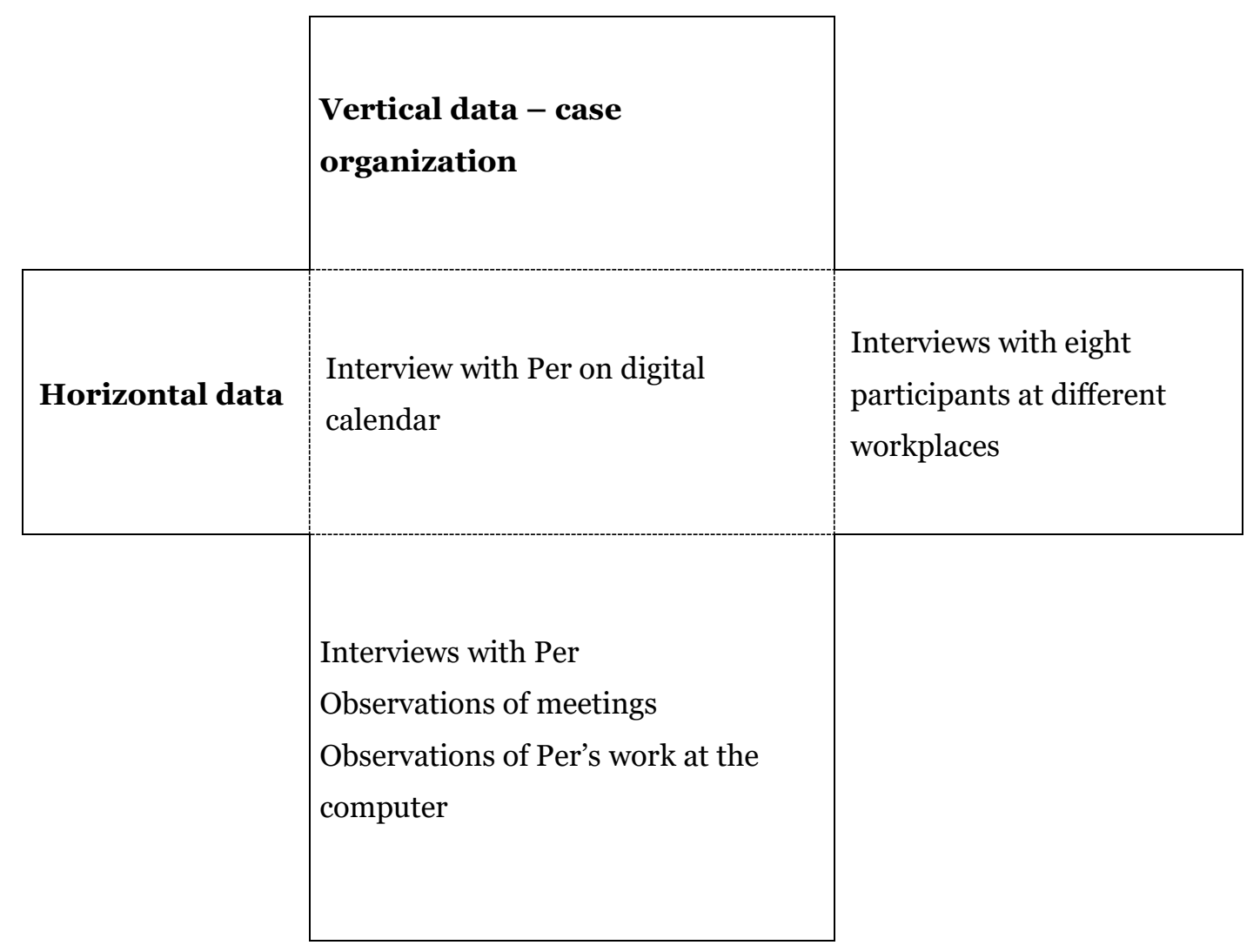

Figure 1. Horizontal and vertical data, with one of the interviews with Per overlapping

With this design we could gain both a deeper understanding as compared to a traditional case study, and the variation or spread that can provide different perspectives and higher reliability and validity (cf. Flyvbjerg 2006). The 
vertical data gave us different types of data, showing the actual use of and interaction with digital calendars. The eight interviews in the horizontal data were based on persons who volunteered, which gave us both interviewees "hospitable to our inquiry" (cf. Stake 1995:4) and "maximum variation" (Flyvbjerg 2006), as they worked in different fields and geographic areas.

The interviews were contextual, meaning that all the participants were sitting at a computer with the digital calendar open during the interviews. For seven of the interviews, we visited the offices of the participants. Two participants were interviewed in their homes. All interviews were conducted in Swedish. The data from the interviews were audio-recorded and transcribed, apart from two that were conducted by telephone, in which the interviewer took notes (the plan was to use Skype and record, but for technical reasons a traditional telephone call was made instead). The transcriptions were done verbatim by one of the authors. Quotes have been translated to English by the authors. All participants also shared two to six print screens each. An overview of the pseudonymized participants can be found in Figure 2.

\begin{tabular}{|l|l|l|l|l|}
\hline Participant & Title & Workplace & Type & Length \\
\hline $\begin{array}{l}\text { Per (key } \\
\text { participant) }\end{array}$ & Head of unit & $\begin{array}{l}\text { Technical development } \\
\text { company }\end{array}$ & $\begin{array}{l}\text { At his office } \\
\text { and recorded }\end{array}$ & 75 min \\
\hline Bernarda & Project manager & Multinational IT-company & $\begin{array}{l}\text { At her office } \\
\text { and recorded }\end{array}$ & 60 min \\
\hline Maria & Project manager & $\begin{array}{l}\text { Higher education } \\
\text { institution }\end{array}$ & $\begin{array}{l}\text { At her office } \\
\text { and recorded }\end{array}$ & 47 min \\
\hline
\end{tabular}




\begin{tabular}{|c|c|c|c|c|}
\hline Magdalena & $\begin{array}{l}\text { Personal care } \\
\text { assistant }\end{array}$ & Private healthcare company & $\begin{array}{l}\text { At her home } \\
\text { and recorded }\end{array}$ & $42 \mathrm{~min}$ \\
\hline Adela & Civil servant & $\begin{array}{l}\text { Higher education } \\
\text { institution }\end{array}$ & $\begin{array}{l}\text { Telephone and } \\
\text { written notes }\end{array}$ & $30 \mathrm{~min}$ \\
\hline Helen & Analyst & Authority & $\begin{array}{l}\text { At her office } \\
\text { and recorded }\end{array}$ & $56 \mathrm{~min}$ \\
\hline Mariana & $\begin{array}{l}\text { Communication } \\
\text { manager }\end{array}$ & Large commercial company & $\begin{array}{l}\text { Telephone and } \\
\text { written notes }\end{array}$ & $45 \mathrm{~min}$ \\
\hline Amelia & Communicator & $\begin{array}{l}\text { Public healthcare } \\
\text { organization }\end{array}$ & $\begin{array}{l}\text { At her office } \\
\text { and recorded }\end{array}$ & $48 \mathrm{~min}$ \\
\hline Alba & $\begin{array}{l}\text { Administrative } \\
\text { officer }\end{array}$ & Authority & $\begin{array}{l}\text { At her home } \\
\text { and recorded }\end{array}$ & $53 \mathrm{~min}$ \\
\hline
\end{tabular}

Figure 2. Interview data

Two of the authors conducted these semi-structured interviews during 2016 and 2017 with the same interview guide, which consisted of three themes:

- Practical questions

- Questions on work processes

- Questions on positive/negative aspects (see appendix). 
In addition, a few specific follow-up questions were posed by email. All participants gave informed consent and had the chance to read this article before publication. The authors signed a confidentiality agreement with the case organization.

\subsection{Qualitative analysis}

The qualitative analysis was conducted in two steps:

1. A data driven, or inductive, analysis where recurring themes as open categories were identified concerning the three research questions. A more condensed data set was constructed from instances of these themes.

2. A specific analysis of agency made on the basis of the data set constructed in step 1.

The specific agency analysis was conducted using the analytical concepts presented in sections 3 and 4:

- Constraints and affordances: which constraints/restrictions and affordances/advantages of using the digital calendar are made relevant by the participants?

- Resistance-mastery-appropriation: do the participants show signs of opposition to (resistance) or general know-how of the digital tool and its sub tools (mastery), or have they integrated them in their identity (appropriation)?

- Agency as a relative phenomenon: do the participants show signs of a sense of high or low agency in relation to the digital calendar? 
Relevant discursive elements were also mapped (Scollon \& Scollon 2004:87), i.e., traced to other discourses, genres, tools and other artefacts that they emanate from or relate to in other ways.

\subsection{Quantitative analysis}

To study the second research question (How do people speak about their calendars and related practices?) in a more reliable manner, we conducted a quantitative analysis based on Systemic Functional Grammar (Halliday \& Matthiessen 2004, Holmberg \& Karlsson 2006). Although we do not apply SFG's specific grammatical approach to agency, the underlying assumption is that how the interviewees speak about the calendar can be interpreted as different views on a more general sense of agency, through an analysis of the ideational metafunction of their utterances. The hypothetical utterance "The calendar makes me confused" (where the calendar is the subject that conducts a material process in which 'me' is a medium) would express a much more restricted agency than, for instance, "I always put it in the calendar" (where 'I' is the subject who conducts a material process).

From the transcripts of the seven recorded interviews, clauses that included the following words were sampled: calendar, email, meeting, invitation, reminder, agenda, task, Outlook, booking, book, reply and click. The clauses in which these words appeared in relation to a shared digital calendar were then analyzed according to:

- Transitivity (Halliday \& Matthiessen 2004:170), including subject (identified in data as $I$, the boss, the calendar, other human actors or other digital actors) and process type (mental, material, verbal or relational; Holmberg \& Karlsson 2006:78-101). 
- The word calendar as participant in processes with the categories goal, scope, phenomenon, attribute and value (Halliday \& Matthiessen 2004, Holmberg \& Karlsson 2006)

- The word calendar as circumstance with the categories matter, role and space (Holmberg \& Karlsson 2006, Halliday \& Matthiessen 2004).

Remaining categories in the SFG system, such as recipient and cause, did not occur. Two members of the research team analyzed the same selection of data to improve reliability.

\section{Analysis}

Below, we present our analyses structured basically from the research questions. The first section starts with a general overview of the use, followed by subsections on the themes stemming from the inductive analysis: text genres and the mode of writing, memory in relation to the mode of writing, and the boundary between public and private. Each section starts with a summary of the findings (in italics), which are later developed and discussed.

\subsection{How do people use the shared digital calendar?}

\subsubsection{Use in general}

The majority of the participants use Outlook as their work calendar, and problems that are mentioned include differing knowledge about the system and external contacts using other systems. Major affordances that are mentioned are the possibility of checking others' calendars and integrating meeting invitations with room booking. For the key participant, preparing meetings with his digital calendar took up much of his desk working time. The care assistant used a booking system with an integrated calendar. 
The different organizations that the eight professionals belong to used Outlook as their work calendar, although one participant (Adela) did not comply, but instead used the Google calendar for her own bookings. Six of the interviewees shared their calendars to some extent. Half of these put specific private bookings into their calendar, and half of them showed that they were occupied but not specifically what they were doing privately. Two of the professionals did not share their calendar, with the exception of a few people.

A core function of Outlook is the affordance to look into the calendars of others (Figure 3).

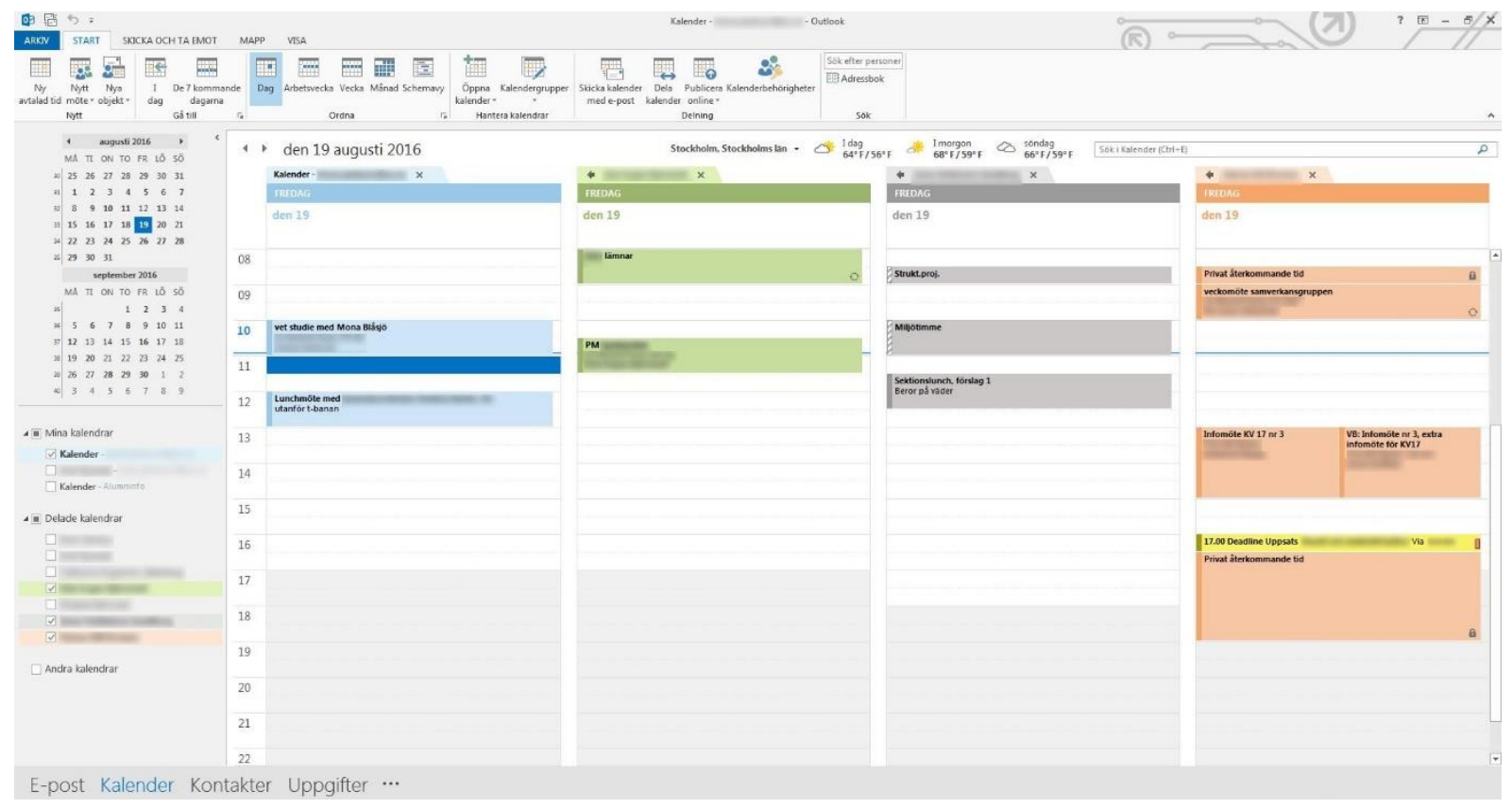

Figure 3. View of different persons' calendars (Maria)

Most of the participants found this function to be very useful, while some resisted being part of the collective time management, e.g., Adela by her noncompliance. To what extent is it possible to show such resistance? Of course, this is different in different organizations. Bernarda says: 
Bernarda: [...] no one says that you can't have a locked calendar. [...] but the thing is, it's embarrassing that you can't see people. What is that person doing, can't see what they're doing? [...]

Interviewer: But it would be weird if like -

Bernarda: Yes. [...] Because then you're not in. Then you don't write yourself into this teamwork that you have to be a part of.

This could be compared to Palen's (1999) observation that using a shared calendar was more an issue of implicit pressure than explicit rules, to Norris' (2005) conception of agency as being strongly connected to free will and choice, and also to the concept of hegemony (Gramsci 1971).

The constraints and problems reported are often connected to diversity. If all communications were performed internally in an organization where everyone mastered the same digital tool with the same level of competence, there would be very few problems, but this is not the case. For instance, it is necessary to communicate with external professionals and other groups (clients, students, etc.) who use different tools. This is reported by, e.g., Maria:

So the easiest thing to do when I book something externally is actually to email people. [...] Yesterday we had a [x] meeting and then I had emailed [certain people] and written in my calendar and was able to invite my boss directly. (Maria)

When booking a meeting with both external and internal participants, Maria and others needed to use email. Adela and Helen used systems other than Outlook, such as Doodle, for inviting when including non-employees, as their calendars could not be searched. Moreover, external professionals and/or persons not using Outlook as a calendar do not automatically receive updates 
and documents added later. This also creates a problem for the inviter, who has to send updates separately to these persons. Thus, both the constraints and the actions the participants take to overcome these issues to increase their agency concern diversity. The differences in people's use of tools constitute a problem, which is dealt with through the use of several digital tools.

Another diversity problem is that all employees do not have the same knowledge about the tool (stated by, e.g., Adela and Amelia). In one case, co-workers were reported as having been shocked when a meeting was cancelled, although it was only the room booking that was cancelled (field notes, small talk before meeting). Alba reported on a collective problem with how to cancel room bookings; i.e., there was not a collective level of mastery of that sub tool. All the problems mentioned above can influence sense of agency; employees cannot always do what they want, at least not in the way they want to.

Managers do not always share their calendars, and when they do, the information that others can see is often reduced, so that it only says "Occupied". This makes it more difficult for co-workers to find out if managers are able to attend meetings right before or after the occupied time slot; "we don't know if they are abroad or what it is", as Per explains.

It is common to wait to be prompted before booking in others' calendars, at least the calendars of managers. Mariana reported sometimes writing separate emails to ask managers for permission to invite. Other participants mentioned their bosses or other colleagues saying things such as “... look in my calendar ...” (Bernarda, cf. quote in Palen 1999: “Browse me!”) or “... put a meeting in my calendar ...” (Helen). It is like a linguistic key or “Open up, Sesame!” This "linguistic key" is a sign of being trusted, which makes the agency larger and thus changes the historical body of a person, and simultaneously widens her/his agency. 
During the hours we observed Per working at his desk, he predominantly engaged in the planning and following-up of meetings, and also stated in interviews that this is a frequent task. The Outlook calendar was constantly an integrated part of literacy practices such as working with documents (creating, finding, revising, sending, ask for participation on) and keeping track of information on meetings and errands (through emails, links, room bookings, lists and other documents).

In some cases, the participants expressed a sense of powerlessness, i.e., a low level of agency, in relation to the digital tool itself:

Sometimes it has a life of its own entirely, changing all the settings in Outlook, and then suddenly the view that I'm used to looks completely different. (Per)

[...] on Mondays there's a colleague who has booked some group room and I don't have anything to do with it, but it shows up in my calendar and she has managed to do something and I don't know why it happens. (Alba)

Automatic updates from the provider and other persons' bookings can be experienced as problems that constrain the users' agency to control what they see in their calendars.

The health care company where Magdalena works seems to not rely extensively on the computer. Rather, they often send text messages on the cellphone and make telephone calls. When someone changes the care assistant's calendar, the change is often backed up by a text message on the phone. This indicates that persons of manual occupations are not expected to be as reliant on their digital calendar. They may need an audible signal to check their digital tools, as they are usually occupied with mobile tasks. This 
finding may seem self-evident, but can give valuable perspective on to how strongly professionals are connected to their digital tools; the calendar and other digital tools are within their historical body.

Agency is also an issue of having the opportunity to use a tool in all its aspects. Firstly, a person has to be familiar with a tool (i.e., have it in their historical body) to be able to use it. The tool can be ever so cleverly designed, but if its functions do not get into the historical bodies of the users, they are not useful. People can use the digital calendar with an underlying current of resistance (as in Adela's non-compliance) and/or a level of more or less mastering the tool (as in Alba not knowing why certain bookings turn up in her calendar). To use a tool in all its aspects is more related to appropriation, to making the tool one's own, an aspect of agency that we will address in greater detail later.

\subsubsection{Text genres and the mode of writing}

A designed possibility for staff on different levels to send meeting invitations can be related to big discourses such as democratization and flat organizations, and contested boundaries between such levels can be seen in concrete interaction. There are connections between the calendar and other text media such as whiteboards and time report systems, as well as big discourses such as managerialism and surveillance. The modality of writing is still predominant, e.g. by sometimes framing verbal communication.

The core sub tool in the Outlook calendar is the meeting invitation (Figure 4), which is integrated with the email function. An invitation is delivered to an email inbox, and when "Accept" is clicked the invitation is transformed into a booking in the recipient's calendar. However, if the recipient does not use the Outlook calendar, the invitation may seem to "disappear". This is one reason why it is sometimes necessary to send a separate invitation as well. 
Accordingly, a constraint concerning the tool for some recipients causes a problem for the sender.

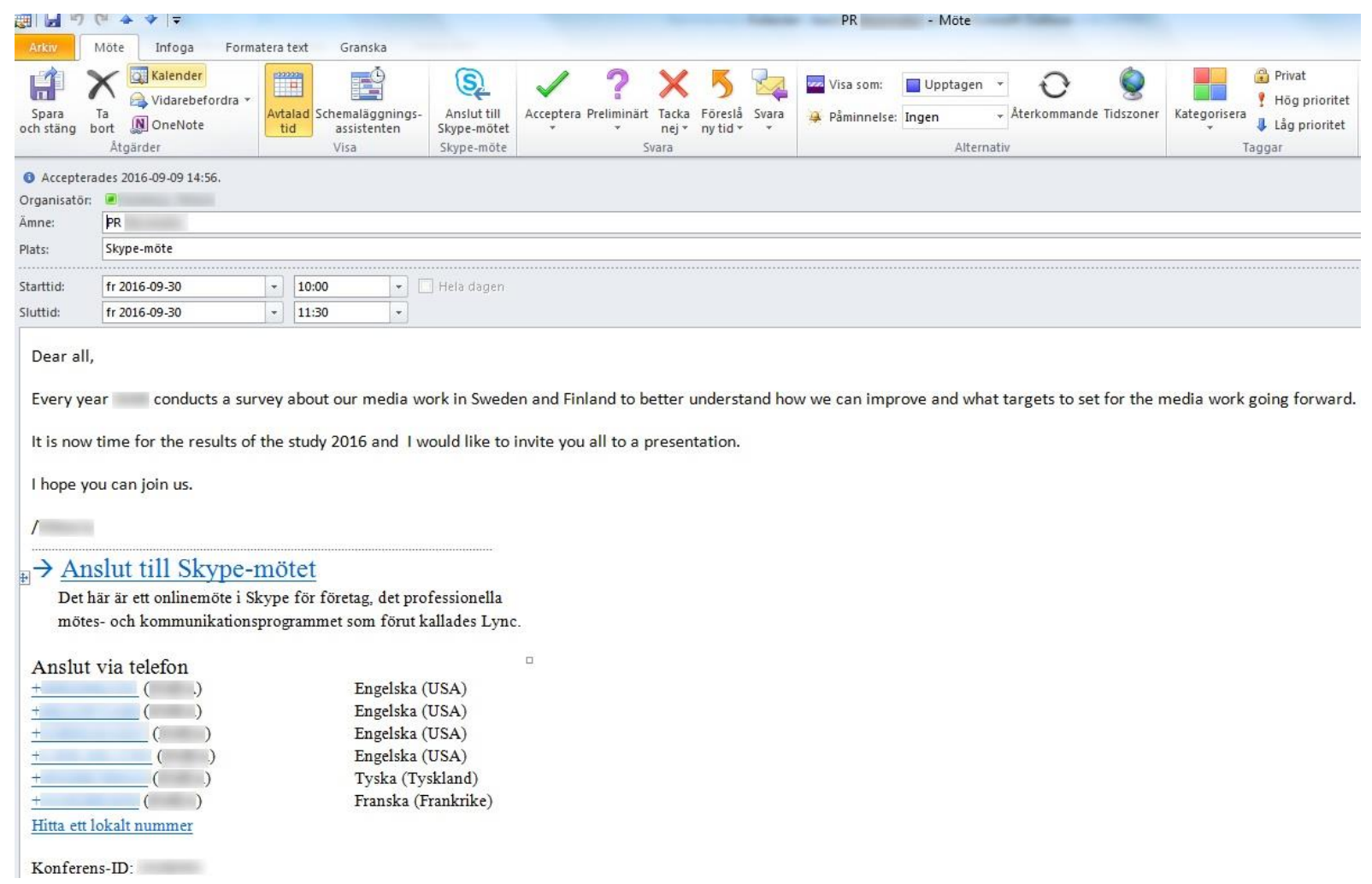

Figure 4. Invitation (with Skype-link; Mariana)

The invitation integrates even more functions, such as "Scheduling assistant", room booking systems and Skype links. One of the great affordances that interviewees mentioned is the ability to attach documents for meetings and to update information, thereby keeping everything collected.

Mapping the text genre of meeting invitations historically, we can see that it has traditionally been used for summoning people, a social practice performed by managers (even if through their assistants) and complied with by other employees. However, the digital design includes the possibility for employees at different levels to invite, as well as the option to mark meetings as Required or Optional. In this sense, it can be said that the genre of digital meeting invitation incorporates other discourses and tendencies such as 
democratization, flat organizations and The New Work Order (Gee, Hull \& Lankshear 1996). Thus, invitations also integrate different discourses of power and agency.

This issue can be illustrated through a situation experienced by the case organization, specifically during an observed meeting in which Per expressed frustration. The meeting focused on external web information concerning a certain phenomenon. The issue of the meeting could be formulated as: How can updated information be communicated, and through which web resources? The meeting invitation had been sent by a project and communication assistant, Gina. The meeting participants were Per (whose role in the meeting was expert of the subject matter); Gina; their boss, Åse; a communication manager; and a project manager. Per's frustration was related to his view that the information was already there, and he was critical of the process ("I was annoyed because I didn't get notice about the way in which this was supposed to be done, on whose order and to what end"; followup email). At the end of the meeting, Åse asked Per if he had anything to add, and he said no:

Per: [...] I'm just a participant in the meeting.

Åse: Yes.

Gina: Yes.

Per: Yes.

Åse: But you can still have something [to say].

Gina: I just wanted to get some more work.

[laughter from several participants] 
Gina's joke, that she wanted something more to do, can be interpreted as face work because she was the implicit target of criticism, and this points to why this case description is relevant here. Gina is the discursively stated initiator of the meeting. She is an administrator, an assistant with an MBA as her highest academic achievement, whereas many others in the same workplace have a PhD. Hence, there is an asymmetric interaction order. As Per's followup email indicates, it was unclear who was responsible for the process and the meeting. Outlook makes it possible for staff in different positions to invite others to meetings. Per and other senior staff had clicked "Accept" for the invitation and joined the meeting. Still, Per expressed criticism on how the process was run, and regarded the meeting as unnecessary. Gina had the technical and formal agency to invite, but an interpretation is that this agency was interactionally challenged at the meeting. The interaction order at the office was somewhat changed or threatened by Gina's use of this option. This sub-case can serve as an interesting example of the context of a meeting invitation in Outlook, where a subordinate employee stands as the inviter. (We asked Gina to give us her version, but she has yet to do so.)

Before the digital revolution, the working day may have been more flexible; now, normally every hour can be categorized by discursive elements such as the Outlook options. This is in line with modern work life's categorizations into economical accounts and managerialism (cf. Tusting 2015, Ledin \& Machin 2015). Helen, who works in a public authority, reported that some colleagues had discussed their old parents during a long lunch and made jokes such as: "What should we put this [discussion] on? [...] What account?" Every activity in her work place has to be marked by an account, written down in a certain digital tool (Figure 5). 


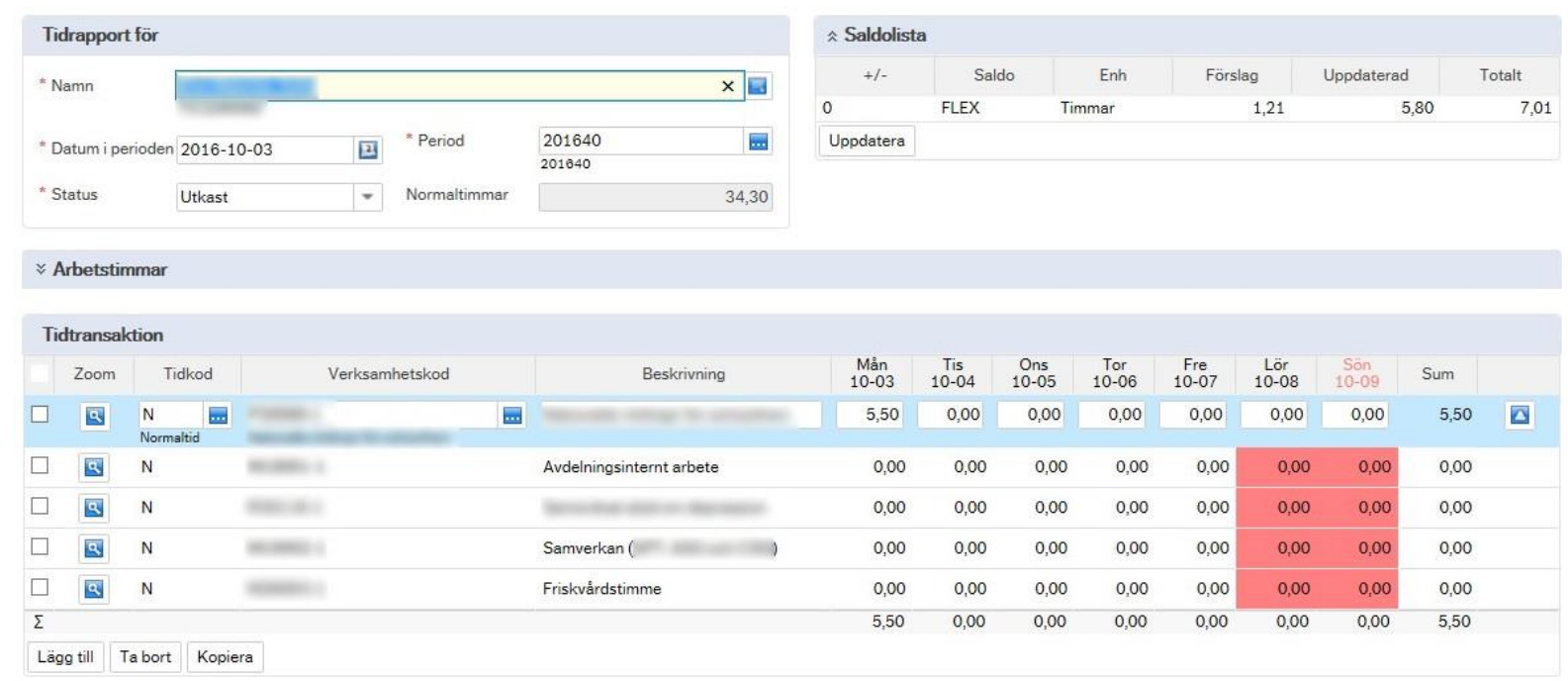

Figure 5. Time report system (Helen)

A discursive similarity here is the categorization in squares with different writing and colors. Time and activities are also shaped with similar squares or blocks on whiteboards. In Figure 6, we can see a so-called Pulse whiteboard. Pulse whiteboards are discursive artefacts emanating from the so-called "Lean Production" model for organizational surveillance and development, which has profoundly influenced Swedish work life (cf. Karlsson \& Nikolaidou 2016).

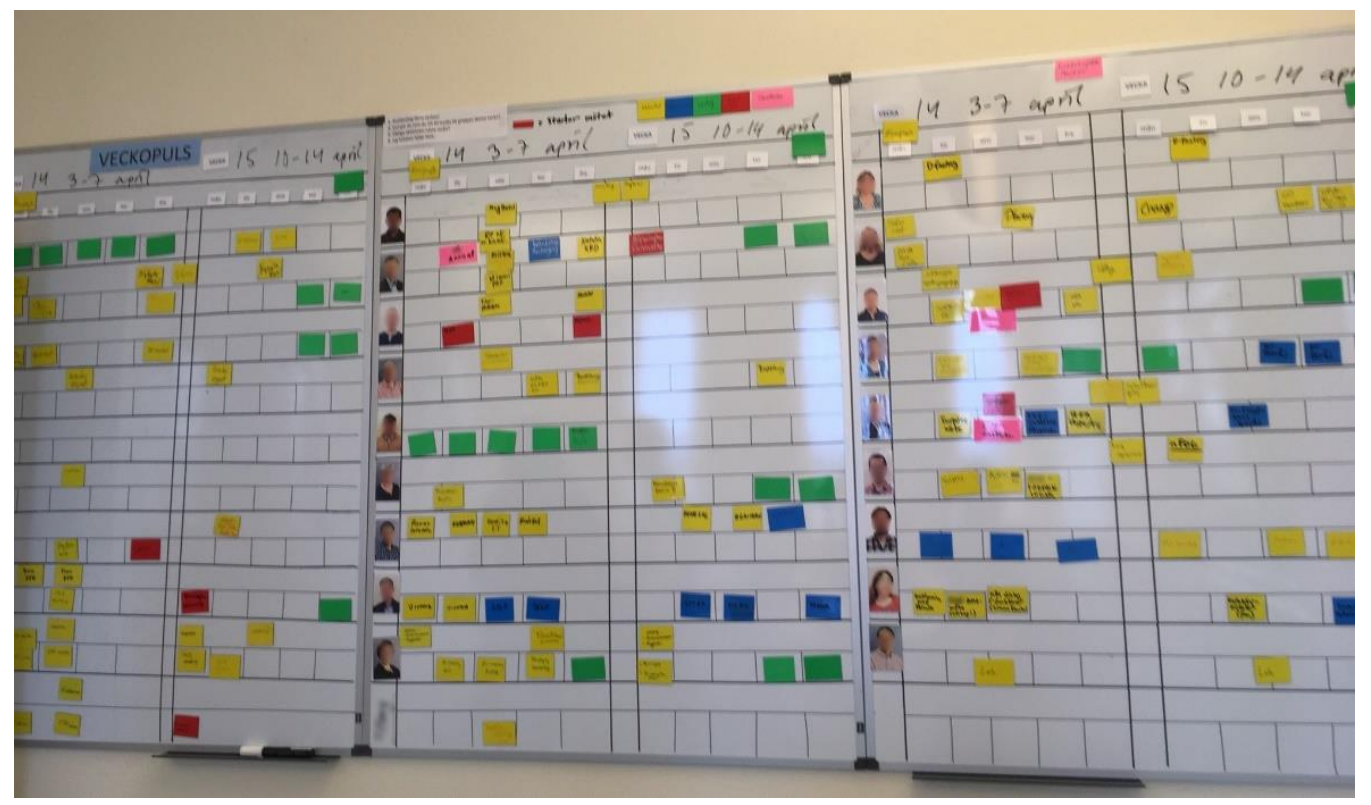

Figure 6. Pulse whiteboard (case organization; dates in top row) 
On a Pulse whiteboard, employees are supposed to show what they plan to work with and what has been achieved using colored magnets. We can see the multimodal similarity - blocks or squares with different colors and writing - with the digital calendar and the tool for reporting and surveilling work activities (Figure 5).

Even when not being surveilled, actions are often anticipated by actions in written mode; several of the participants reported often writing to colleagues to ask if and when they could make telephone calls, and also wrote this telephone call into their calendars (e.g., Mariana and Bernarda). What was earlier just a verbal telephone call is now often framed by written text elements.

Moreover, the importance of writing can be exemplified by the predominant text element "Subject" in an invitation. How users fill in this field is crucial for the success of the meeting, Bernarda stated. Moreover, the importance of what is actually written in the calendar bookings can be illustrated by a short narrative from Adela: She interpreted an acronym in her calendar as a meeting with management, but one letter was wrong, and she was surprised to see representatives from an external organization, with a similar acronym as a name, entering her office. As Adela had made a small mistake in her writing in the calendar, she also made a mistake on what to expect.

\subsubsection{Memory in relation to the mode of writing}

In this section, we identify the issue of memory as partly related to a scale of access, where the digital mode makes memory collective and independent of place, and the mode of paper makes the memory individual and dependent on place. Some participants had developed their own strategies for dealing with errands over time, thus showing a high level of appropriation and agency. 
Mapping the discursive role of calendars over time, we can see that they have always been used for keeping memories of what to do (Payne 1993, Geisler 2003). Compared to shared calendars such as logbooks or booking lists in use before the digital revolution, e.g., at hospitals and hairdressers, the digital calendar makes the memory collective at the same time as accessible, regardless of place. The old type of calendar was placed in the physical workplace, and although all employees could see it, they had to be there to do so. The collective memory has become spaceless (cf. Säljö 2012).

The analysis shows that people can put a different "amount of memory" into the calendar compared to their own minds. As Mariana said:

I'm used to getting a reminder 15 minutes before a meeting. This week there was a meeting without a reminder, and I missed it. I have surrendered my brain a little to the calendar.

She had become dependent on the digital tool, thus sometimes experiencing a sense of lower agency. Amelia and Bernarda reported that in order to be remembered, a meeting or task has to be written down (cf. Hassenzahl 2015).

The calendar is also used for to-do points and other types of information. There is a sub function for tasks, but not all participants used it. Some users had their own strategies and discursive actions to deal with this type of "nonappointment information to aid memory" (Palen 1999:19), as Amelia said:

[...] so that I really set aside [time], know that I have to do it this afternoon. Maybe didn't do it exactly between one and two but. [...] But like that afternoon it has to be done. [...] Like an extra reminder to myself when there is something important. (Amelia) 
Without using the sub function for tasks, Amelia wrote in timeslots for her tasks (Figure 7). She can be said to have appropriated the digital calendar to the degree of using the sub function designed for scheduling meetings for the affordance of scheduling her own one-person activities (cf. Geisler [2001] reporting on the same phenomenon).

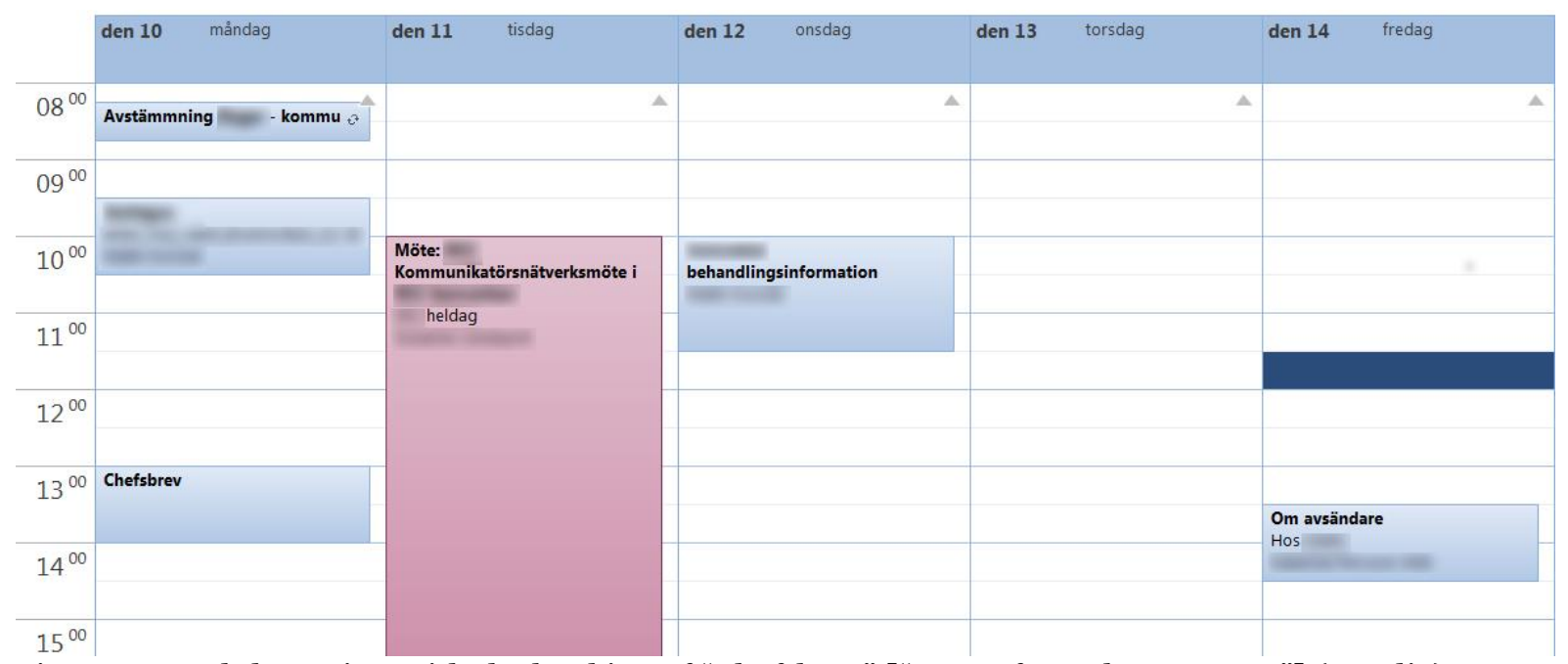

Figure 7. Week-long view with the booking of "Chefsbrev" ["Letter from the manager"] (Amelia)

Two other participants, Helen and Per, used a certain technique for maintaining their memory of errands (according to interviews and observations of desk work). There are different notetaking tools, of which often OneNote is integrated with Outlook. Still, Helen and Per used paper notebooks in a strategy comprising these steps or literacy practices:

1) During a meeting, taking notes with dates in a paper notebook (Figure 8)

2) Later, searching in the digital calendar for the date of this meeting (using the search tool, e.g., writing a name) 
3) Searching in the paper notebook for that date

4) Checking the notes in the notebook.

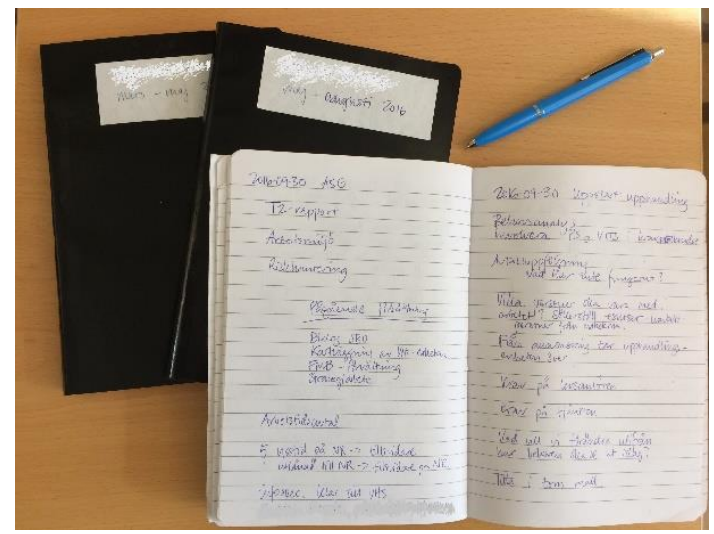

Figure 8. Paper notebooks (Helen)

As the reason for his handwritten notes, Per stated "variation"; using digital tools all day long, he appreciated the divergent practice of handwriting. Nevertheless, our analysis points to these participants having developed their own affordances by combining different artefacts and literacy practices to deal with work life demands. Together with the above-mentioned practice of using a sub function for something other than it was intended to, this serves as an example of how people can design their own literacy practices, at a high level of appropriation and agency.

\subsubsection{Boundary between private and public}

The boundary between the public and private sphere has been contested and made discursive by the technical settings of the calendar tool. There are individual options, but not everyone in the workplace knows how to keep more information from the collective, i.e. they do not master these functions. The analysis shows language choice as another individual strategy for keeping information from others and still blocking time slots. An emerging tendency is for employees' private aspect becoming more textually mediated 
(through the calendar) at the expense of private physical artefacts in the workplace.

In the Outlook tool, there are choices of how much persons allow others to see of their bookings. Options include either keeping the calendar from the shared mode totally or opening the calendar and all of its bookings to everyone, or locking certain bookings, so that others can see that one is occupied, without more detailed information. There are also more specific options (Figure 9.)

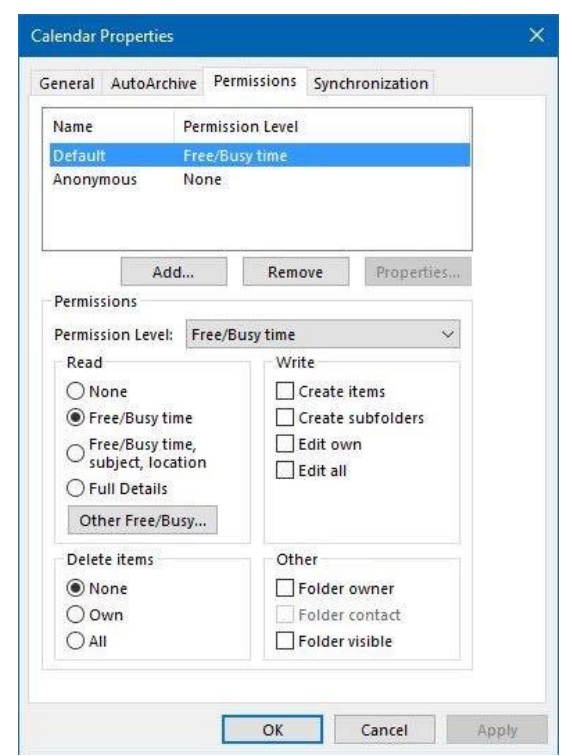

Figure 9. Options for permission levels for how much others can read in one's calendar

Moreover, in the data of print screens, we can see a tendency among staff who have open calendars to often lock their private bookings. In their calendars, they can see that they are going to a certain party or concert, but others can only see that they are occupied. However, several of the participants also put in quite specific information about their private bookings without locking them, e.g., "Rehearsal with choir” (Mariana). As Helen said: “[...] perhaps you don't write down personal stuff. [...] You censor a bit, like don't write them down." Thus, there may be invisible practices that cannot be seen on the print screens. 
Nevertheless, there is a certain space for users to resist the discourses of sharing and openness. This space or affordance is actually built in the digital calendar, as one can choose not to show specific information about one's activities with everyone. This type of agency may be restricted in some workplaces, though.

The boundary between private and public can also be marked by language choice. One participant with many international contacts says:

Bernarda: [...] there was this guy in France, pretty alert and good at languages [...]. "Hello Bernarda, I saw you are ledig today". So I think he had figured out that ledig means vacation. So I've kept that ledig because I think it's a bit fun, it's a bit exciting. [...]

Interviewer: And perhaps you can say that they main thing is that they can see that you're busy?

Bernarda: Yes, that's right.

Interviewer: It doesn't matter what you're doing but -

Bernarda: No that's right. And the further away they are, the less they take an interest [...].

Thus, the modality of writing and the language choice is not as important as the "blocking" of space made by a non-verbal modality (a square, a color). In international organizations, leisure-time activities can be written in a local language, which may have the meaning potential (Van Leeuwen 2005) "private". Again, we can see how employees can use functions for something other than what they were intended or designed for. 
The threatened boundary between private and public, free time and work, is also obvious in the fact that most people access their job calendar (and email) in their spare time and at locations other than the office. Amelia mentioned seeing meeting invitations when using her cellphone outside the office, and the personal assistant Magdalena was supposed to check messages during her spare time, in case she should be asked to take a shift for someone else.

Bernarda showed us her 'activity-based' office where most employees do not have a desk of their own. The office had about 100 desks for 300 employees, "and it works" (Bernarda). Everyone had a lockable cupboard for keeping their personal belongings from day to day, so "Clips are gone and binders are gone and like everything is ...” (Bernarda). Normally, the private sphere was on display in the office through family photos, comical note-board texts and other artefacts placed in one's own office area (Moberg et al. 2016). Simultaneously, employees had the choice of how much to tell their colleagues about their private life. However, in an activity-based office, private artefacts were not on display, or they were put away in a cupboard at the end of the day (cf. Toft \& Berg Nielsen 2016). In the digital calendar, most employees had to share information about private activities, at least the daytime slots when they were busy with such activities, but sometimes also what these time slots included, such as doctor's appointments or gym sessions.

One can conclude that the boundary between private and public has been challenged and changed. Employees are sharing their private sphere both to lesser and greater degrees. They may reveal less of their personal belongings and more information on their out-of-office activities. A possible hypothesis is that sharing is becoming more textual and less artefactual in other ways. 


\subsection{How do people speak about their calendars and related practices?}

The SFG analysis of the transcribed interview data shows that the calendar is mostly spoken about as an object of human action and a spatial container. The interviewees speak about themselves and their colleagues mostly as active agents in relation to the calendar.

According to our interpretation of the transitivity analysis, sense of agency is generally high among the interviewees. Material verb processes are dominant (70 \%), which is expected, but moreover they very rarely have the calendar or other digital artefacts as subject, which could have been the case if the interviewees had seen themselves as objects of the digital tool. On the contrary, $I$ is the subject in $27 \%$ of the sampled cases, and other human actors in $38 \%$ of the cases, in which most cases are you (in the sense of one, Swedish $d u / m a n$ ) and we. The frequency is very low for referring to one's boss (less than $1 \%$ ), the calendar (less than $1 \%$ ) or other digital tools (4\%) as subject of actions. Generally, the interviewees speak about themselves and their colleagues as subjects or active agents in relation to the digital calendar.

In the role as participant in processes of the word calendar, referring to digital calendar, the most frequent role (ca. $50 \%$ ) is goal, i.e., the calendar is the object of an action: “... if I bring up my calendar here ...” (Helen).

The second most frequent category (ca. $25 \%$ ) is attribute, i.e., the calendar is the object of possession or other relational process: “... you always have your calendar with you ...” (Amelia).

As circumstance, the predominant role of the word calendar is space, i.e., something that is written and looked into: “... when you're looking in your calendar" (Bernarda). 
As mentioned above, the cases where calendar functions as subject are very rare, as there are only two in the data: "Then the calendar is very unreliable" and "the calendar is helpful".

Thus, the linguistic quantitative analysis indicates that the participants do not regard their own agency as low as the manager in the pilot study (Gravett 2018), which inspired the current study.

\section{How can the literacy practice of using a shared digital calendar be related to issues of agency?}

This section has the character of discussion. Returning to the third research question, we attempt to summarize the analyses and discuss some general issues in light of the three key analytical concepts of MDA - discourses in place, interaction order and historical body.

Concerning discourses in place, some big discourses (cf. Gee 1999) involved in the use of digital calendars are globalization and marketization, as Outlook is provided by one of the largest IT corporations in the world. However, there is still competition, where other IT providers are on display, such as Google, Apple and smaller solutions, e.g., Slack or Podio. The competition can be labelled a discursive one, which may strongly influence users in their everyday communicative practices: How do I handle the situation where one participant out of several do not use Outlook? What are the effects of the latest automatic update? What do I put in the calendar for everyone at the office to see? Some of the practices we have found (such as writing notes in a paper notebook instead of a digital tool) could possibly be interpreted as ways for actors to resist the power of the digital tools and the big discourses involved with them (cf. Lillis 2013:147, on the affordance of notebooks as a space of one's own), thus protecting their agency. An additional discursive aspect is that several participants claim writing to be an important mode even in the digital age. 
This can also be seen in the finding that verbal interaction is often framed by writing, such as telephone calls being prompted by emails (cf. Jakobs \& Spinuzzi 2014, who mention informal communication as being more textual in today's workplaces). The digital calendar in itself can be regarded as such a writing-based tool, framing the verbal interaction of meetings. Digital calendars do not textualize facts or subject matters (cf. Karlsson \& Landqvist 2018, Berge 2001), but upcoming and past events; although first and foremost they textualize such actions as inviting to meetings and searching for information (cf. Karlsson \& Nikolaidou 2016, Tusting 2015).

Concerning interaction order, the tendencies in modern society for flat organizations and The New Work Order (Gee, Hull \& Lankshear 1996) to take away layers of managers and place more self-surveillance on employees can partly be seen in the use of the shared digital calendar (cf. Ledin \& Machin 2015, Tusting 2015). Different employees, not only managers, can influence the time management and work of others through such tools as the digital calendar. This type of surveillance or management agency is especially "designed-in" in certain Outlook subfunctions such as scheduling and search tools. Outlook also influences what private information people share with others.

Concerning historical body, technical and linguistic access to the calendars of others can be seen as a concrete quality of certain individuals, crucial for their agency, as it is a sign of being trusted. Moreover, which social setting a person comes from, such as a new employee coming from another organization, influences which digital tools s/he is familiar with. Digital experience, or digital literacy (cf. Knutson et al. 2012), forms a major social demarcation of different employees into hierarchical levels. This, in turn, shows the affordance of the digital calendar as a tool of power and management in today's workplaces. 


\section{Methodological discussion and conclusions}

We hope to have contributed with an analytical approach using both broader "horizontal" data from different workplaces and deeper "vertical" data from one workplace.

The quantitative analysis needs to be regarded as a minor attempt to obtain a rough picture of how participants talk about their digital practices. The results need to be interpreted in light of that, when asked what one does and how, it is natural for one to use a high quantity of first person pronouns. Moreover, the research question guiding that analysis was partly owed to the fact that the only valid information one can get from interview data is how people speak about something, not what they actually do.

As Norris (2005) states, there is no one-to-one relation with what people say about their agency in local interaction and how this agency is performed on a more general level. In our data, there are examples such as Per being confused by automatic updates changing his user interface, while simultaneously having a high level of digital literacy, as observed when he conducted his everyday work via the computer. This also points to the very complex nature of digital work life. With our analytical approach, we have tried to capture some of this complexity.

The analysis also provides concrete examples of how social actors and discourses in place are strongly related. Participants using the Outlook calendar carry it "within them", in their historical body, and act it out and use it in several ways. One way is choosing to put a part of one's memory into the digital tool. Moreover, when the calendar is shared, the individual memory is made more collective (cf. Säljö 2012). There is something akin to an umbilical cord between professionals and their digital tool, which may be self-evident 
today, but was made visible by the comparison with the care assistant, for whom this connection was not as strong.

Returning to the three levels of agency outlined in section 5, we can see that quite a few participants experience restricted agency in control of the functions within the tool itself. To get more control, some people develop their own strategies by combing different media and using functions for ends other than what they were designed for, which can be seen as a high level of appropriation. In the immediate context, the participants generally claim to appreciate and take advantage of the functions of searching in others' calendars and booking rooms. However, these affordances are limited by the fact that not everyone else uses Outlook or has the same competencies. Differences in the historical bodies of individuals working together influence their interaction order in a wider context, and thus the agency of individuals to do what they would like to do with the digital calendar. Moreover, the interaction order affects which access individuals have to others' calendars. A certain action within the interaction order of the wider context (such as a manager saying "Put it in my calendar") can cause a change within the tool itself (technical access), enabling an individual higher agency in the immediate context (to do bookings in that manager's calendar). Looking at the broader context, we can also see big discourses (cf. Gee 1999), such as democratization and surveillance. Discourses such as these reach the individuals partly through the discursive artefact of the digital calendar, widening their agency to, e.g., invite superior staff to meetings, and simultaneously constraining it by threatening the freedom to arrange one's work day without surveillance through a shared calendar and/or 'reaching out' to private leisure time (“colonization of personal-life”; Geisler 2006:12).

The use of the digital shared calendar forms a crucial literacy practice in modern workplaces. Applied linguistics could bring other such scarcely acknowledged literacy practices and textual tools in contemporary society into 
the analytical light. Especially interesting in this regard could be to look in greater detail at the individual strategies of actors, such as how they combine different modes and artefacts, and the general issue of how their actions are connected to discursive access to certain texts and tools.

\section{References}

Bakhtin, M. (1986). Speech genres and other late essays. Austin: Univ. of Texas Press.

Bell, A. (2016). Succeeding waves. Seeking sociolinguistic theory for the twenty-first century. In: Coupland, Nikolas (red.) (2016). Sociolinguistics: theoretical debates. Cambridge: Cambridge University Press. P. 391-416

Berge, K. L. (2001). Temaintro: Retorik \& genre. Rhetorica 18. P. 4-16.

Berge, K. L. (2007). The rhetoric of science in practice: experiences from Nordic research on subject-oriented texts and text cultures. In: Fløttum (Ed.), Language and discipline perspectives on academic discourse. Cambridge Scholars Publishing. P. 40-64.

Buzzo, D. \& Merendino, N. (2015). Not all days are equal: Investigating the meaning in the digital calendar. In: CHI EA '15 Proceedings of the 33rd Annual ACM Conference Extended abstracts on Human factors in computing systems. P. 489-501. 
Darics, E. (2017). E-leadership or "How to be boss in Instant Messaging?" The role of nonverbal communication. International Journal of Business Communication. http://journals.sagepub.com/doi/pdf/10.1177/2329488416685068

Deumert, A. (2014). Sociolinguistics and mobile communication. Edinburgh: Edinburgh University Press.

Flyvbjerg, B. (2006). Five misunderstandings about case-study research. Qualitative inquiry 12(2). P. 219-245.

Gee, J. P. (1999). An introduction to discourse analysis. Theory and method. London: Routledge.

Gee, J. P., Hull, G. A., \& Lankshear, C. (1996). The new work order: Behind the language of the new capitalism. Boulder: Westview Press.

Geisler, C. (2001). Textual objects: Accounting for the role of texts in the everyday life of complex organizations. Written communication 18(3), 296325 .

Geisler, C. (2003). When management becomes personal: An activitytheoretic analysis of Palm technologies. Writing selves/writing societies: Research from activity perspectives. Fort Collins, CO: WAC Clearinghouse.

Giddens, A. (1984). The constitution of society: outline of the theory of structuration. Cambridge: Polity Press.

Goffman, E. (1983). The interaction order. American Sociological Review 48(1), 1-17. 
Golden, A. G., \& Geisler, C. (2006). Flexible work, time, and technology:

Ideological dilemmas of managing work-life interrelationships using personal digital assistants. The Electronic Journal of Communication/La Revue Electronique de Communication 16(3-4), 1-18.

Golden, A. G. \& Geisler, C. (2007). Work-life boundary management and the personal digital assistant. Human Relations 60(3), 519-551.

Gramsci, A. (1971). Selections from the prison notebooks of Antonio Gramsci. London: Lawrence and Wishart.

Gravett, A. (2018): "Ibland känner jag mig som en kropp som bara går in och ut genom rum." En verksamhetsanalys av en regionschefs kommunikativa arbetsdag. In: Blåsjö \& Jonsson (Eds.): Mångfald, möten och mejl. En forskningsöversikt och tre fallstudier om arbetslivskommunikation. MINS 64. Institutionen för svenska och flerspråkighet, Stockholms universitet. P. $55^{-102 .}$

Halliday, M. A. K. \& Matthiessen, C. (2004). An introduction to functional grammar. 3. ed. London: Arnold.

Hassenzahl, M. (2015). Commentary for alt.chi paper "Not all days are equal: Investigating the meaning in the digital calendar". In: CHI EA '15 Proceedings of the 33rd Annual ACM Conference Extended abstracts on Human factors in computing systems. P. 489-501.

Holmberg, P., \& Karlsson, A. M. (2006). Grammatik med betydelse. En introduktion till funktionell grammatik. Uppsala: Hallgren \& Fallgren. 
Hund, P. M., Dowell, J., \& Mueller, K. (2014). Representation of time in digital calendars: An argument for a unified, continuous and multi-granular calendar view. International Journal of Human-Computer Studies 72(1), 111.

Irwin, A. 2011. Social constructionism. In: Wodak, Johnstone \& Kerswill (Eds.), The SAGE handbook of sociolinguistics. Los Angeles: SAGE. P. 100112.

Jakobs, E. \& Spinuzzi, C. (2014). Professional domains. Writing as creation of economic value. In: Jakobs \& Perrin (Eds.), Handbook of writing and text production: communication competence, language and communication, problems, practical solutions. Berlin: De Gruyter Mouton. P. 359-384.

Jones, R. H. (2005): Sites of engagements as sites of attention. In: Norris, S. \& Jones, R. H. (Eds.) Discourse in Action: Introducing Mediated Discourse Analysis. London: Routledge. P. 141-154.

Jones, R. H. (2008). Good sex and bad karma: Discourse and the historical body. In: Bhatia, Flowerdew \& Jones (Eds.), Advances in Discourse Studies. London: Routledge. P. 245-257.

Jones, R. \& Norris, S. (2005). Introducing agency. In: Norris \& Jones (Eds.), Discourse in action: Introducing Mediated Discourse Analysis. London: Routledge. P. 169-171

Karlsson, A. M. (2007). Text, situation, praktik. Om ramar och resurser för tolkning av texter i arbetsrelaterade skrifthändelser. I: Gunnarsson \& Karlsson (Eds.), Ett vidgat textbegrepp. TeFa-rapport 46. FUMS, Institutionen för nordiska språk. Uppsala universitet. P. 27-40. 
Karlsson, A. M. (2009). Positioned by reading and writing: Literacy practices, roles, and genres in common occupations. Written Communication, 26 (1): 53-76.

Karlsson, A-M \& Landqvist, M. (2018). Gränsöverskridande meningsskapande: Om relevansen hos begrepp som text och sakprosa för förståelsen av hälsokommunikation. I: Sakprosa 10:1. P. 1-31.

Karlsson, A. M., \& Nikolaidou, Z. (2016). The textualization of problem handling: Lean discourses meet professional competence in eldercare and the manufacturing industry. Written Communication 33(3), 275-301.

Knutsson, O; Blåsjö, M.; Hållsten, S \& Karlström, P. (2012). Identifying different registers of digital literacy. The Internet and Higher Education 4(15), 237-246.

Kress, G. (2009). Multimodality: A social semiotic approach to contemporary communication. London: Routledge.

Ledin, P., \& Machin, D. (2015). How lists, bullet points and tables recontextualize social practice: A multimodal study of management language in Swedish universities. Critical discourse studies 12(4), 463-481.

Lillis, T. M. (2013). The sociolinguistics of writing. Edinburgh: Edinburgh University Press.

Luff, P., Hindmarsh, J. \& Heath, C. (Eds.). (2000). Workplace studies: Recovering work practice and informing system design. Cambridge University Press.

Moberg, B. R., Due, B. L. \& Nielsen, M. F. (2016). Sted og rum. In: Nielsen, Due, Gravengaard, Nielsen, Nielsen \& Toft (Eds.), Kommunikation $i$ 
internationale virksomheder. Bind 1. Copenhagen: Samfundslitteratur. P. 6576.

Norris, S. (2005). Habitus, social identity, the perception of male domination - and agency? In: Norris \& Jones (Eds.), Discourse in action: Introducing Mediated Discourse Analysis. London: Routledge. P. 183-196.

Norris, S. \& Jones, R. H. (Eds.) (2005). Discourse in Action: Introducing Mediated Discourse Analysis. London: Routledge.

Palen, L. (1999). Social, individual \& technological issues for groupware calendar systems. CHI '99 Proceedings of the SIGCHI conference on Human Factors in Computing Systems. P. 17-24.

Payne, S. J. (1993). Understanding calendar use. Human-Computer Interaction 8(2), 83-100.

Schmidt, K., \& Bannon, L. (2013). Constructing CSCW: The first quarter century. Computer Supported Cooperative Work (CSCW) 22(4-6), 345-372.

Scollon, R. (2001). Mediated discourse: the nexus of practice. New York: Routledge.

Scollon, R. (2008). Analyzing public discourse: discourse analysis in the making of public policy. New York: Routledge.

Scollon, S. (2005). Agency distributed through time, space and tools: Bentham, Babbage and the census. In: Norris \& Jones (Eds.), Discourse in action: Introducing mediated discourse analysis. London: Routledge. P. 172182. 
Scollon, R. \& Scollon, S. (2003). Discourses in place: language in the material world. London: Routledge.

Scollon, R. \& Scollon, S. (2004). Nexus analysis. Discourse and the emerging Internet. London: Routledge.

Scollon, R., Scollon, S. \& Jones, R. 2012. Intercultural Communication: A discourse approach. Third edition. Oxford: Wiley-Blackwell.

Sharples, M. (Ed.). (2012). Computer supported collaborative writing. Springer Science \& Business Media.

Smart, G. (2006). Writing the economy. Activity, Genre and Technology in the World of Banking. Oakville, CT: Equinox.

Stake, R. E. (1995). The art of case study research. Thousand Oaks, California: Sage.

Säljö, R. (2012). Literacy, digital literacy and epistemic practices: The coevolution of hybrid minds and external memory systems. Nordic Journal of Digital Literacy 7(1), 5-19.

Toft, T. \& Berg Nielsen, E. (2016). Det fysiske kontor. In: Due, Gravengaard, Nielsen, Nielsen \& Toft (Eds.), Kommunikation i internationale virksomheder. Bind 1. Copenhagen: Samfundslitteratur. P. 265-297.

Tusting, K. (2015). Workplace literacies and audit society. In: Snell, Shaw \& Copland (Eds.), Linguistic ethnography. Interdisciplinary explorations. London: Palgrave Macmillan. P. 51-70.

Van Leeuwen, T. (2005). Introducing social semiotics. London and New York: Routledge. 
Vygotskij, L. S. (1978). Mind in society: the development of higher psychological processes. Cambridge, Mass.: Harvard U.P.

Wertsch, J.V. (1998). Mind as action. New York: Oxford University Press. 